\title{
The Interest of a Wife in California Community Property
}

$T_{\text {HE complexity of the problems concerming marital property rights }}$ is not novel. Legal history indicates that such rights sprang from local customs and often varied in different communities of the same country. ${ }^{1}$ In so far as the community property system is concerned even its ancestry is not entirely agreed upon by those who have interested themselves in the matter, ${ }^{2}$ and those jurisdictions which accept it as the basis of marital property rights have no uniform theory as to the exact nature of the property interests existing in the parties to the marital relation. In some, ownership is said to reside in a legal personality known as the community, which is considered as distinct from the parties, in others the husband and wife are treated as co-owners on one basis or another, and in still others the entire title is in the husband subject to an interest vesting in the wife only when the community is terminated..$^{3}$ This latter theory led to the comment that the wife's community interest begins when the community ends. In so far as the California commumity property law is concerned, problems involving title or ownership have been frequently confused with those involving the right of management and control. Indeed, it has been suggested that much useless effort has been expended in the endeavor to determine the theoretical nature of the property interest which the respective spouses have in community property, rather than in seeking to determine the extent to which either may exercise the rights or powers ordinarily incident to ownership. ${ }^{ \pm}$Conceding the propriety of this comment, nevertheless it inust be admitted that the theory of ownership in comununity property has played an important part in the developinent of the commumity property law of this state. Without attempting a detailed review of all the court decisions in this regard, their development will be briefly traced with reference to the interest of the wife in community property during the existence of the community and the effect of successive legislative enactments changing the control of the respective parties to the marital relation over disposition of the coinmunity property during the existence of the community.

12 PoIIOCK \& MaITIAND, History OF ENGLISH LAw (2d ed. 1898) 399.

2 McKay, Comarunity Property (2d ed. 1910) \$8; CaL. JuRus. (1930 Supp.) $8,9,10$.

32 Pollock \& Matriand, op. cit. suppra note 1, at 400, 401; CAL. JuRIs. (1930 Supp.) 92.

${ }^{4} \mathrm{Ibid}$. at $92,93$.

5 Kirkwood, Ozonership of Community Property in California (1933) 7 So. CatIr. L. Rev. 4, 5, 6. 


\section{Judicial Construction of Statutory Provisions from 1850 ro 1917}

The decisions of our supreme court indicate some initial disagreement or at least doubt as to the exact nature of the wife's interest in the community property. The Constitution of 1849 provided that a married woman might hold property as her separate property and provided further that laws should be passed "more clearly defining the rights of the wife in relation as well to her separate property as to that held in common with her husband." 8 In 1850 the legislature in compliance with the constitutional provision enacted a statute purporting to define the wife's separate property, the husband's separate property and also the so-called "common property." 7 In 1853 the supreme court in commenting upon the interest of the wife in the "common" (subsequently and now usually termed "community") property as created by the act of 1850 , said by way of dictum: "The one-half of it is EQUTTABLY the right of the plaintiff [wife]." 8 Yet the same court, speaking two years later, while commenting upon the same statute, and in an endeavor to define the respective interests of the spouses in the common property, expressed the opinion that:
“... our Statute has done away with the common law right of dower, and substituted in place, a one-half interest in the common property. . . . The husband and wife, during coverture, are jointly seized of the property, with a half interest remaining over to the wife, ... This is a present, defi- nite, and certain interest, which becomes absolute at his [the husband's] death, ..." 8

In 1860 and prior to any substantial statutory change with respect to the interest of the wife the supreme court, speaking through Chief Justice Field and without referring to the two cases heretofore mentioned, stated:

"The interest of the wife is a mere expectancy, like the interest which an heir may possess in the property of his ancestor." 10

Ten years later and still before any substantial statutory change, the supreme court, in referring to community property, said:

"It belongs to the matrimonial community, and not less to the wife than to the husband. It is true that the interest of the wife therem pending the marriage has been termed ' $a$ mere expectancy' ... ; but while, perhaps, no other technical designation would so nearly define its character, it is, at the same time, an interest so vested in her, as that husband cannot deprive her of it by his will ...., nor voluntarily alienate it for the mere purpose of divesting her of her claims to it ... Her mere right in the

${ }^{6}$ Art. XI, \$14.

7 Cal. Stats. 1850, p. 254.

8 Kashaw v. Kashaw (1853) 3 Cal. 312, 322.

9 Beard v. Knox (1855) 5 Cal. 252, 256.

10 Van Maren v. Johnson (1860) 15 Cal. 308, 311. 
community property is as well defined and ascertained in contemplation of law, even during the marriage, as is that of the hushand." 11

More than two decades later the prevailing judicial opinion returned to the theory that the title to cominunity property was in the husband and that the interest of the wife during the contmuation of the community was a mere expectancy. In 1896 a divided court held:

"The estate of the wife in the community property is a creature of the statute, and is, of course, just what the statute has made it. It has always been pretty inuch what it now is, though formerly, upon the dissolution of the community by the death of the wife, one-half of the property descended to her heirs. . . . The legal title to the community property is in the husband. He has the absolute dominion and control of it, and the wife has no right or title of any kind in any specific property, but a possible interest in whatever remains upon the dissolution of the comnumity otherwise than by her own death. This cannot be classified as any species of estate known to the law." 12

This theory was shortly after again approved, ${ }^{13}$ nor was the supreine court induced to abandon it because of an amendment in 1891 to section 172 of the Civil Code requiring the wife's consent in writing to all gifts and voluntary transfers of community property made by the husband. ${ }^{14}$

\section{In 1905 a statute was enacted providing:}

"All property which shall pass, by will or by the intestate laws of this state, from any person who may die seized or possessed of the same... shall be and is subject to a tax heremafter provided for. . ."15

In determining whether the surviving wife's share of the coinmunity property was subject to the tax the court considered several of its earlier decisions heretofore mentioned ${ }^{16}$ and held that, since all elements of ownership in community property were vested in the husband, "upon the death of the husband the wife takes one-half of the community property as heir," and consequently that her interest was subject to the tax. ${ }^{17}$ Upon a subsequent consideration of the effect of the amendment of 1891 to section 172 of the Civil Code the supreme court stated:

11 De Godey v. Godey (1870) 39 Cal. 157, 164.

12 In re Burdick (1896) 112 Cal. 387, 393, 44 Pac. 734, 735.

13 Spreckels v. Spreckels (1897) 116 Cal. 339, 48 Pac. 228.

14 Cal. Stats. 1891, p. 425.

15 Ibid. 1905, p. 341.

16 Beard v. Knox, supra note 9; De Godey v. Godey, supra note 11; In re Burdick, supra note 12 .

17 Estate of Moffitt (1908) $153 \mathrm{Cal} .359,95 \mathrm{Pac}$. 653. In 1917 the Inheritance Tax Statute was amended so as to provide: "For the purpose of this act the one-half of the community property which goes to the surviving wife on the death of the husband, under the provisions of section one thousand four hundred two of the Civil Code, shall not be deemed to pass to her as heir to her husband, but shall, for the purpose of this act, be deemed to go, pass, or be transferred to her for valuable and adequate consideration and her said one-half of the community shall not be subject to the provisions of this act." Cal. Stats. 1917, p. 881. 


\begin{abstract}
"There is nothing in the language [of the amendment of 1891] to express the idea that the title [to community property] does not, as before, remain wholly in him. [the husband]. The provision is merely for a limitation upon his power to dispose of it. . . In view of the long settled doctrine that the entire estate therein is in the lusband during the marriage relation, a doctrine that had become a fixed and well understood rule of property, it is not to be supposed that the legislature would have made a change of so radical a character without plain language to that effect." 18
\end{abstract}

Some years later the supreme court after a detailed reconsideration of its previous decisions concerning the nature of the wife's interest in community property prior to 1917 , agam concluded that:

\begin{abstract}
"... the husband is the owner of the cominunity property; that except for such restrictions as the legislature may have authority to impose he has the unqualified right to dispose of it and that the wife has but a mere expectancy and not a title or interest which she would convey by joining in the deed." 19
\end{abstract}

\title{
II. Judictal Construction of Statutory Provistons from 1917 To 1923
}

In 1917 the legislature further limited the control of the husband over community real property and correspondingly extended the control of the wife thereover by adding Civil Code section 172a, which provides that the wife must join in any instrument by which the community real property is conveyed, encumbered or leased for a period longer than one year. ${ }^{20}$ The same legislature added a provision enabling a nuarried woman with cause for divorce to secure a division of the community property without a dissolution of the marital relation. ${ }^{21}$ It also amended the Inheritance Tax Act so as to exempt from the tax the one-half interest in the comnunity property which the wife took upon the death of the husband. ${ }^{22}$ It was strongly urged upon the court that the effect of the amendments of 1917 was to create in the wife a vested interest. The court, however, relying in part upon the absence of plain language expressly indicating the legislative intent so to do (the requirement previously suggested in Spreckels v. Spreckels ${ }^{23}$ ) concluded:

"We are, therefore, clearly of the opinion that the amendments to the Civil Code, adopted in 1917, did not operate to change such rule to the extent of creating in the wife a present vested interest in the property of the community during the continuance of the marriage relation." 24

This decision was reached in spite of a different conclusion theretofore

18 Spreckels v. Spreckels (1916) 172 Cal. 775, 782, 158 Pac. 537, 539.

19 Roberts v. Wehmeyer (1923) 191 Cal. 601, 612, 218 Pac. 22, 26.

20 Car. Crv. Code §172a, added by Cal. Stats. 1917, pp. 829, 830.

21 Ibid. $\$ 137$, as amended by Cal. Stats. 1917, p. 35.

22 Cal. Stats. 1917, p. 881.

23 Supra note 18.

24 Stewart v. Stewart (1926) 199 Cal. 318, 340, 249 Pac. 197, 206. 
arrived at by the United States Circuit Court of Appeals and based upon the effect of the 1917 amendment to the Inheritance Tax Act. ${ }^{25}$ It is true that the supreme court in the same opinion did state:

"We wish to say in conclusion that we are in accord with the intimations from time to time reflected by this court ... to the effect that the interest of the wife in the property of the community during the continuance of the marriage relation while it has not yet reached the status of a vested interest therein, is and has always been ... a much more definite and present interest than is that of an ordinary heir." 26

However, on a subsequent appeal in the same case the court, while adhering to its conclusion as to the nature of the wife's interest, explained its language last referred to by stating that such rights as a wife had in community property, and which an heir usually did not have, were given to her:

"... in order that she might protect herself against the fraudulent and inconsiderate acts of her husband and therehy preserve the community property intact until the dissolution of the marriage." 27

It has been suggested ${ }^{28}$ that the court in reaching its conclusion in the above case of Stewart v. Stewart overlooked the effect of the 1917 amendment to section 137 of the Civil Code which afforded a wife who had cause for divorce a right to petition for a division of the community property without seeking to extinguish the marital status. It seems doubtful if this amendment, if indeed overlooked, would have altered the decision of the court in view of its oft repeated statement that statutes affecting the control which the spouses may exercise over community property are not to be construed as intended to affect the theory of ownership therein in the absence of plain or express language so declaring. It is true also that this portion of the amendment in question afforded the wife an "affirmative power rather than a mere negative or veto power." 29 However, it seems to the writer more probable that the court would construe the amendment as intended to protect the wife's interest by denying to a husband, who had through his misconduct afforded the wife cause for divorce and incident thereto the right to obtain a division of the community property, a right to object to the division of the community property simply because the wife did not desire to exercise all the rights afforded her by his misconduct. Furthermore, the husband's interest in the community, whatever it may be and whenever acquired, is held by him subject to the laws for the enforcement of his personal marital obligations and may be taken or divested

25 Wardell v. Bluin (C.C.A. 9th, 1921) 276 Fed. 226.

26 Stewart v. Stewart, supra note 24, at 342, 249 Pac. at 207.

27 Stewart v. Stewart (1928) 204 Cal. 546, 552, 269 Pac. 439, 441.

28 Kirkwood, op. cit. supra note 5, at 9.

$29 \mathrm{Ibid}$. at 10. 
to accomphish their enforcement. ${ }^{30}$ This construction would be even more probable since the subsequent amendment to the same section in $1927^{31}$ giving the husband similar rights where the wife has afforded him cause for divorce. It could hardly be urged with reason that this latter amendment was imtended to create in the husband additional ownership in the community property.

\section{Judicial Construction of Statutory Provisions from 1923 то 1927}

In 1923, section 1401 of the Civil Code was amended to provide:

"Upon the death of either husband or wife, one-balf of the community property belongs to the surviving spouse; the other one-half is subject to the testamentary disposition of the decedent, and in the absence thereof goes to the surviving spouse, subject to the provisions of section one thousand four hundred two of this Code." 32

This placed the husband and wife upon an equal basis so far as concerned their respective rights to the community property upon the dissolution of the community by the death of either party. Its obvious effect was two-fold. First, it afforded the wife the power of testamentary disposition over one-half of the community property existing at her death. This, like the 1917 amendment to Civil Code section 137, gave her a positive and affirmative right of disposition over community property and correspondingly limited the husband's interest in it. The supreme court has held that this limitation upon the husband's interest in the community property does not apply to property acquired before the amendment, smce such an application would deprive the husband of property without due process of law. ${ }^{33}$ This is consistent with previous decisions of the court holding that statutory changes substantially affecting the rights of the spouses in community property are not retroactive. The same principle was applied in construing the 1891 annendment to Civil Code section 172 forbidding the husband to give away the community property or convey the same without valuable consideration without the wife's consent thereto in writing. ${ }^{34}$ It was again applied im construing the 1917 amendment adding Civil Code section 172a which provides that the husband can not sell, convey or encumber the community real property or lease it for a period longer than one year unless the wife joins in the instrument. ${ }^{35}$

The second effect of the 1923 amendment to Civil Code section 1401

30 Goetting v. Goetting (1926) 80 Cal. App. 363, 252 Pac. 656.

31 Cal. Stats. 1927, p. 441.

32 Ibid. 1923, pp. 29, 30.

33 McKay v. Lauriston (1928) 204 Cal. 557, 269 Pac. 519.

34 Spreckels v. Spreckels, supra note 13.

35 Stewart v. Stewart, supra note 24. 
was to enable the wife to take all of the community property upon the death of the husband intestate whereas theretofore under similar circumstances she had received only one-half thereof, the other one-half going to the husband's descendants. Inasmuch as the title to the entire community had theretofore been regarded as being in the husband, the amendment in this regard would seem to concern the law of succession or inheritance and the supreme court has so held. ${ }^{36}$ It was further held that, since the right of succession is not a vested property right in the potential heir or successor but rather one governed by the law in effect at the time of the death of the owner, this part of the amendment would apply to community property existing at the death of the husband no matter when acquired..$^{37}$ It is to be noted that the terminology einployed in the 1923 amendinent to Civil Code section 1401 suggests a possible difference in the nature of the property interest as between the one-half which the surviving spouse takes regardless of the testamentary disposition by the decedent and the other one-half which the survivor takes only in case the decedent dies intestate. As to the former the section provides that upon the death of either it "belongs" to the survivor, but as to the latter the section provides that it "goes" to the survivor. Mr. Justice Preston in a concurring opinion indicated it to be his opinion that the effect of the amendment in question was to create a vested interest in the wife in the community property acquired after its passage. ${ }^{38}$ However, the United States Circuit Court of Appeals has indicated a contrary opinion in holding that the wife could not make a return on any portion of the income received froin community property acquired subsequent to $1923,{ }^{30}$ and prior to the 1927 amendment. In view' of the policy of our supreme court ${ }^{40}$ in declining to construe statutory changes in the control of the spouses over community property as changing the theory of property therein in the absence of plain language to that effect, it may be doubted if the amendment in question will be held to do so. It seenis inore probable that the power of disposition placed in the wife would be construed as a testamentary power created by law over property, title to which is in the husband. ${ }^{41}$

It has been urged that this amendment had an important effect upon the extent to which the wife may avoid gifts or voluntary con-

36 Estate of Phillips (1928) 203 Cal. 106, 263 Pac. 1017.

37 Ibid.

38 Cutting v. Bryan (1929) 206 Cal. 254, 259, 274 Pac. 326, 328.

39 Hirsch v. United States (C.C.A. 9th, 1932) 62 F. (2d.) 128, cert. den., (1933) 289 U.S. 735.

40 Spreckels v. Spreckels, supra note 18; Stewart v. Stewart, supra note 24.

41 Cat. JuRIs. (1930 Supp.) 108, 109. 
veyances of community property made by the husband without the consent of the wife in violation of the provisions of Civil Code sections 172 and 172a. For the purpose of this article the discussion will be confined to the extent to which the wife may set aside such conveyances after the death of the husband. It may be observed, however, that, in so far as she has a right to set aside such conveyances during the existence of the community, the extent to which she may set them aside should be the same unless otherwise expressly limited by statute. In discussing the extent to which a wife may avoid unlawful conveyances of community property made by the husband, the successive statutory limitations placed upon his authority to make transfers inter vivos should be kept in mind. As was hereinbefore indicated, until 1891 the husband had the management and control of the community property with the same absolute power of disposition (other than testamentary) as he had of his separate estate. ${ }^{42}$ In 1891 his power of disposition was limited in the following respect:

"... provided, however, that he cannot make a gift of such community property, or convey the same without a valuable consideration, unless the wife, in writing, consent thereto." 43

As an original proposition it might be and indeed was contended that the purpose of the amendment was to preserve the community property intact during the existence of the community and to make it impossible for the husband to impair that property by transfers of the nature mentioned in the proviso, with the result that any such attempted transfers would be absolutely void and of no effect. However, in a proceeding brought by the executors of a deceased husband and a deceased wife for the purpose of setting aside gifts of community property acquired after the amendinent of 1891 , and made by the husband without the consent of the wife, the supreme court held otherwise, stating:

"We are satisfied that the proviso of 1891 does not render a gift of community property by the husband without the consent of the wife void as to him, nor confer upon him, in his life time, or upon his personal representatives after his death, any right or power to revoke the gift or recover the property. ... Neither does the proviso purport to vest in the wife, during the marriage, any present interest or estate in the community property given away by the husband without her written consent. . . . If it confers upon her, during the marriage, any right respecting such gifts, it is nothing nore than a right to revoke the gift and, if necessary, sue to recover the property, not as her separate estate, but to reinstate it as a part of the commumity property. ... We do not find it necessary to determine whether this right accrues to her at once when the gift is made, or whether it remains in abeyance until her expectancy in the community property becomes vested by the dissolution of the marriage by death or divorce." 44

42 Cal. Stats. 1850, p. 254. Re-enacted in 1872 as CAL. CIv. CoDE $\$ 172$.

43 Ibid. as amended by Cal. Stats. 1891, p. 425.

44 Spreckels v. Spreckels, supra note 18, at 782, 158 Pac. at 539. 
Subsequently, in Dargie v. Patterson, ${ }^{45}$ the supreme court had occasion to determine the extent to which such voidable conveyances could be set aside. The case involved a suit brought by a widow to set aside a conveyance of community property, acquired after the amendment of 1891, made by the husband without consideration and without the consent of the wife. In accordance with its previous decision in Spreckels v. Spreckels, the court held that the conveyance was not void, but voidable at the option of the wife, and further held that the conveyance could be avoided by the wife only as to one-half of the property. Its conclusion was based upon the following reasoning:
". . . the only logical conclusion is that the wife's right to assail the con- veyance where, as here, the action is brought after the husband's death, is limited to an undivided half of the property. During his lifetime the husband, notwithstanding the statutory limitation upon his power of disposition, is the owner of the community property. The proviso at- tached to section 172 does not impair his right to dispose of the property, so far as concerns his own interest and that of tbose claiming under him. If he had made no conveyance, the widow would, upon his death, have been entitled to one-half of the property in question, as of all other community property. The other balf would have passed to his heirs or devisees, and the widow, as such, would have had no interest in it. His heirs or devisees are bound, as he himself was bound, by the conveyance made. Why, then, should the widow's claim extend to any more than the one-half which would pass to her as survivor of the community. The privilege of avoiding the gift is conferred upon her as a means of protecting her interest in the community property. We see no reason why, in assailing the gift, she should enjoy greater rights than she would bave had if the gift had never been made. . . . It is not necessary to the widow's protection that she attack the transfer, except as to one-half, and she should not be allowed to attack it for the benefit of others who are bound by it." 48

In 1917 Civil Code section 172 was amended so as to confine its scope to community personal property and section 172 a pertaining to the management of community real property was added. ${ }^{47}$ The latter section provided that the wife must join with the husband in executing any instrument by which community real property or any interest therein is leased for a period longer than one year, or is sold, conveyed, or encumbered. Although there are suggestions that a conveyance by the husband in violation of this latter provision is void ${ }^{48}$ it has now been definitely held to be merely voidable and only at the option of the wife. ${ }^{49}$ As before stated, the 1923 amendment to Civil Code section

45 (1917) 176 Cal. 714, 169 Pac. 360.

46 Ibid. at $718,169 \mathrm{Pac}$. at 361 .

47 Cal. Stats. 1917, p. 829.

48 Bone v. Dwyer (1925) 74 Cal. App. 363, 240 Pac. 796.

49 Pretzer v. Pretzer (1932) 215 Cal. 659, 12 P. (2d) 429; Trimble v. Trimble (1933) 86 Cal. Dec. 543, 26 P. (2d) 477; Travelers Ins. Co. v. Fancher (1933) 86 Cal. Dec. 551, 26 P. (2d) 482; Schelling v. Thomas (1929) 96 Cal. App. 682, 274 Pac. 755. 
1401 (now Probate Code section 201) caused all of the community property to pass to the wife in case the husband died intestate rather than one-half of such property as previously. The supreme court in two recent decisions, Trimble v. Trimble and Travelers Insurance Company $v$. Fancher, ${ }^{50}$ has held that this amendment affords the wife no greater right to avoid unlawful conveyances made by the husband during his life-time, the right being still confined to one-half of the property so conveyed. It would seem that there are persuasive reasons for arriving at a different conclusion at least as to community property acquired after 1923.

Trimble v. Trimble involved a proceeding brought by a widow to set aside conveyances of two parcels of community real property made by the husband by way of gift where she neither joined in the deeds nor consented to the transfer. Title to one parcel had been acquired in 1915 when the law prohibited the husband from making gifts of community real property without the written consent of the wife and title to the other parcel was acquired in 1925 when the law required that the wife must join in the execution of the instrument by which any commimity real property was conveyed. When title to the second tract was acquired, there was in effect the 1923 amendment to the Civil Code section 1401 enabling the wife to succeed to all of the community property upon the death of the husband intestate. It was urged upon the court that because of this amendment the wife, in order to protect her interest as a survivor of the community, should be able to set aside the conveyance as to all of the property. The majority of the court were of a contrary opinion, however, and held that the extent of the right of the wife to avoid the conveyances was not affected by the amendnent in question. In reaching this conclusion the majority opinion states:

"This section of the code (1401) in providing for the descent of onehalf of the community property of the decedent spouse, simply announces a rule of succession to community property after the death of one of the spouses, and does not purport to fix or define the mterest of the spouses in the community property during the life of the spouses, (Estate of Phillips ...). The rights of the spouses in community real property, as we have seen, is controlled by Sec. $172 \mathrm{a}$ of the Civil Code already referred to. The authorities we have cited, ${ }^{51}$ as previously shown, hold that by this section of the code the husband may, without the consent of his

50 Both supra note 49.

51 In addition to the case of Estate of Phillips referred to in the portion of the opinion above quoted the court relied primarily upon Spreckels v. Spreckels, supra note 18; Dargie v. Patterson, supra note 45; McKay v. Lauriston, supra note 33; and Lahaney v. Lahaney (1929) $208 \mathrm{Cal}$. 323, 281 Pac. 67. It is to be noted that all of these cases on their facts involved situations presented before the 1923 amendment to Cat. Crv. Code \$1401. 
wife, dispose of by deed his half of the community property, and such conveyance is binding upon his wife after bis death. This right was in no way dependent upon nor limited nor affected by the provision of section 1401 of the Civil Code either before or after its amendment in 1923. . . . From the foregoing authorities we are of the opinion that the deeds executed by the deceased without consideration and without the consent of his wife are valid conveyances as to one-half of the property sought to be conveyed, but may be avoided by his wife as to her half of said comununity property." 52

Travelers Insurance Company v. Fancher involved an interpleader proceeding brought by the insurance company to determine the conflicting claims to the proceeds of certain insurance policies upon the hife of one Charles Fancher as between the widow and the guardian of the minor children of said decedent. It appeared that during his marriage and between the years 1925 and 1929 the insurance company issued to the decedent various insurance policies upon his life in which policies the decedent's minor children without consent of the wife were designated as sole beneficiaries. All the premiums on the policies were paid out of community property. It had been determined in this state that a policy of insurance taken out on the life of the husband and paid for out of community funds constitutes community property. ${ }^{53}$ If the husband designates as beneficiary a third party who contributes no consideration it constitutes an inchoate gift which becomes complete upon his death and if made without the consent of the wife miglit, as the law existed prior to the 1923 amendment to Civil Code section 1401, be avoided by her as to one-half of the proceeds. ${ }^{54}$ Consistent with its conclusion in Trimble $v$. Trimble the majority of the supreme court held that the amendment in question did not affect the extent to which the gift might be avoided by the wife which is still limited to one-lialf of the proceeds. In the opinion of the district court of appeal adopted by the supreme court it is stated:

"Nowhere, however, as appellant seems to contend, does the amended code section purport to vest in the wife, during the life time of the husband, any additional ownership in his share of the community property, nor give to her any right of control thereover. It will be seen, therefore, that the enactment of said amended section in no way affected the power of the husband, as it theretofore existed under the doctrine

5286 Cal. Dec. at 547, 548, 26 P. (2d) at 480.

52 IJnion Mutual Life Ins. Co. v. Broderick (1925) 196 Cal. 497, 238 Pac. 1034; Blethen v. Pacific Mutual Life Ins. Co. (1926) 198 Cal. 91, 243 Pac. 431; New York Life Ins. Co. v. Bank of Italy (1923) 60 Cal. App. 602, 214 Pac. 61. A contrary view has been nuaintamed by some courts and text writers based upon the theory that since the proceeds are acquired and payable only upon the death of the husband and not during the existence of the community they are not community property. McKAY, op. cit. supra note 2, at 324, 325; CAL. JURIS. (1930 Supp.) 39.

54 Blethen v. Pacific Mutual Life Ins. Co.; New York Life Ins. Co. v. Bank of Italy, both supra note 53 . 
of the Spreckels and Dargie cases, supra, to make a valid gift of his share of the community property to take effect upon his death." 55

In both of these decisions the court seems to conclude that if it be held, as it is held, that the effect of the 1923 amendment to Civil Code section 1401 is not to create in the wife a vested interest in the community property then it must follow upon the authority of Dargie v. Patterson that a surviving wife's right to avoid a conveyance of community property in violation of the provisions of Civil Code sections 172 and 172a is confined to one-half of such property. But does it so follow? It is stated in Dargie v. Patterson that "the privilege of avoiding the gift is conferred upon her as a neans of protecting her interest in the community property." "T6 The supreme court has repeatedly held that such interest never was, at least prior to 1927 , a vested interest. Indeed in Dargie v. Patterson the court recognized this by stating: "During his life time the husband, notwithstanding the statutory limitation upon his power of disposition, is the owner of the community property." ${ }^{27}$ The interest in the community property, to protect which the court permitted the wife to avoid the conveyance as to one-half of the property, was the interest which she took from the husband by succession upon the termination of the cominunity by his death. From 1850 until 1923 this interest had been confined by the statute of succession to one-half of the community property. ${ }^{58}$ The recognition of this principle was the basis of the holding in Estate of Moffitt ${ }^{59}$ which was to the effect that upon the death of the husband the wife took onehalf of the community property by succession, which one-half was subject to tax under the Inheritance Tax Law as it then stood. When her right to succession was increased from one-half to the entire community property it would seem that under the decision in Dargie v. Patterson she should be permitted to protect that right as against a conveyance by the husband in violation of Civil Code sections 172 and 172a and upon the husband's death avoid such conveyance in its entirety. It is stated in Travelers Insurance Company v. Fancher:

"In other words, the fact that by virtue of said amended section the surviving wife is substituted for the husband's descendants as inheriting heir to his share of the community property remaining undisposed of at the time of his death places her in no better position to assail the validity of the husband's gift of his share of the community property, after his death, than his descendants would have heen in, under the rule of the Spreckels and Dargie cases, if such substitution had not been made." 60

5586 Cal. Dec. at 553, 26 P. (2d) at 484.

50 Supre note 45 , at 718,169 Pac. at 361 .

57 Ibid.

58 Cal. Stats. 1850 , p. 255 ; ibid. 1861 , p. 311 ; ibid. $1863-4$, p. 363 ; CAx. Crv. CODE $\$ 1401$ as enacted in 1872 .

59 Supra note 17.

60 Supra note 49 , at 553,26 P. (2d) at 484. 
The court seems to overlook the essential difference between the interest of the wife in community property, to the acquisition of which her membership in the commumity has contributed, and the interest of other heirs of the husband. It seems to overlook the fact that the community property "is peculiarly a creature of statute" and, regardless of whether the wife has any vested property interest therein during the existence of the community and even though her interest may be in the nature of an expectancy, that that interest "is and always has been ... a much more definite and present interest than is that of an ordinary heir." ${ }^{11}$ If, as the supreme court has stated, the rights of a wife in reference to community property, which are not enjoyed by an "ordinary" heir, were afforded her for the purpose of protecting her expectancy "against the fraudulent and inconsiderate acts of the husband and thereby preserve the community property intact until the dissolution of the marriage," ${ }^{62}$ what more appropriate occasion would there be to exercise these rights and preserve the community property intact than when, but for a conveyance made by the husband in violation of statute, the property would have remained in the community and passed to her upon the husband's death? The court seems to be influenced by the realization that to permit the wife to avoid such conveyances in their entirety will prevent the husband during his life- . time from making gifts of community property to his children without the wife's consent. It states:

"Moreover it is evident that if appellant's theory of the law were adopted, a husband would be precluded entirely from making any provision for his children out of his share of the community property, by way of life insurance, unless his wife consented thereto, or unless in addition to designating his children as beneficiaries in the policy, he confirmed the inchoate gift thus made to them by executing a will to that effect." 03

Surely it cannot be reasonably contended that community property in the nature of a life insurance policy is to be treated, in so far as transfers by the husband are concerned, on a different basis than any other kind of community personal property. A very apparent and significant element of the 1923 ainendment to Civil Code section 1401 would seem to be the change in the policy of the law in reference to the potential interest of the children in all community property. It would seem that in so far as the community property is concerned the legislature by this amendment intended to entrust the protection of the children of the marriage to the judgment of the surviving spouse save as limited by the wishes of the other expressed in his or her final testamentary disposition of one-half of such property. ${ }^{\text {et }}$

61 Stewart v. Stewart, supra note 24, at 342, 249 Pac. at 207.

62 Stewart v. Stewart, supra note 27 , at 552, 269 Pac. at 441.

6386 Cal. Dec. at 553, 26 P. (2d) at 484.

64 Trimble v. Trimble, supra note 49 , at 549,26 P. (2d) at 481 ; Cax. Jurus. (1930 Supp.) 162. 


\section{Statutory EnactMent of 1927}

\section{In 1927 Civil Code section 161a was enacted, providing:}

"The respective interests of the husband and wife in the community property during the continuance of the marriage relation are present, existing and equal interests under the management and control of the husband as is provided in sections 172 and $172 \mathrm{a}$ of the Civil Code. This section shall be construed as defining the respective interests and rights of husband and wife in community property." 65

It has been suggested that this statutory change did not affect the theory of ownership in community property. ${ }^{66}$ However, it seems more probable that it was an attempt to comply with the doctrine of the supreme court as set forth in the Spreckels and Stewart cases $^{67}$ and to state in plain language the legislative intent to change the theory of ownership in community property thereafter acquired and afford the wife a vested interest therein. ${ }^{68}$ It seems that this view is supported by the second sentence of the section, and also by the fact that the section was enacted within a year after the supreme court's decision in Stewart v. Stewart ${ }^{69}$ which again emphasized the need of "plain" language to bring about such a result. Such a construction seems to have been adopted by the federal courts. ${ }^{70}$

If it be held that the effect of the enactment in 1927 of section 161a of the Civil Code is to create in the wife a vested interest in the community property acquired thereafter, interesting questions still

65 Cal. Stats. 1927 , p. 484.

68 Car. JuRIS. (1930 Supp.) 108. In Legis. (1927) 16 CaITF. L. Rev. 68 it is stated: "The declaratory form of the section makes possible its interpretation by the court as the formal opinion of the legislature as to the status of the wife's interest under pre-existing legislation, rather than a legislative statement of changed and enlarged interest on either part." This interpretation was repudiated by the supreme court in Stewart v. Stewart, supra note 27.

67 Spreckels v. Spreckels, supra note 18; Stewart v. Stewart, supra note 24.

68 Kirkwood, op. cit. supra note 5, at 1, 11, 12, 13.

60 Supra note 24.

70 The United States Circuit Court of Appeals certified the following questions to the United States Supreme Court: "(1) Under the applicable provisions of the Revenue Act of 1928 unust the entire community income of a husband and wife domiciled in California be returned and the incoine tax thereon be paid by the husband? (2) Has the wife under section 161a of the Civil Code of California such an interest in the community income that she should separatcly report and pay $\operatorname{tax}$ on one-half of such income?" As to the first of these questions the Supreme Court answered "NO" and as to the second "YES." United States v. Malcolm (1931) 282 U.S. 792. The Court based its conclusion upon the authority of Poe v. Seaborn (1930) 282 U.S. 101; Goodell v. Koch (1930) 282 U.S. 118; and Hopkins v. Bacon (1930) 282 U.S. 122. These cases involved similar questions arising as to the tax upon the income of community property in the states of Washington, Arizona and Texas, respectively, and were decided upon the theory that in each of these states the wife had a vested interest in one-half of the community property equal to that of the husband, subject to varying rights of inanagement and control in the latter. 
remain as to the exact nature of that interest. Is the wife's interest to be treated as that of a joint tenant, a tenant in common, the interest of a co-partner or of a tenant by the entirety or is it none of these? It has already been pointed out that the Constitution of 1849 gave the legislature the power to define and limit the nature of the wife's interest in the marital property. ${ }^{71}$ This was not changed by the Constitution of 1879 which merely defined the separate property of the husband and wife. ${ }^{72}$ It still follows, therefore, that: "The estate of the wife in the community property is a creature of statute, and is, of course, just what the statute has made it." 73

In view of dissimilar statutory provisions prevailing in other states where the community property system is in effect the decisions of the courts of such states are of doubtful assistance. It has long been provided in Civil Code sections 161 and 682:

"A husband and wife may hold property as joint tenants, tenants in common, or as community property."

"The ownership of property by several persons is either:

1. Of joint interests;

2. Of partnership interests;

3. Of interests in common;

4. Of commumity interest of huband and wife."

These sections had been repeatedly considered by the supreme court prior to the enactment of Civil Code section 161a, but, because of long established legal doctrine and of other statutory provisions, had been held inadequate to create in the wife a present vested interest in the community property. It would seem, however, that the provisions of section 161a expressly defining the interest of the husband and wife in community property should be construed in the light of these sections and that, as to community property acquired after 1927, the husband and wife hold not as joint tenants, tenants in common, nor in co-partnership but rather that each has a present title and ownership to an equal portion of such community property, the wife's interest being subject to such power of management and control in the husband as public policy expressed through appropriate statutory provisions may deem desirable. ${ }^{.4}$ This view has already been advanced by at least one commentator. ${ }^{75}$

William $M$. Simmons.

Hastzings Coltiege of the LaW, San Franctsco, California.

71 Art. XI, \$14.

72 Art. XX, \$8.

73 In re Burdick, supra note 12, at 393, 44 Pac. at 735.

74 Poe v. Seaborn, supra note 70.

75 Kirkwood, op. cit. supra note 5, at 13, 17. 